\title{
Length-Weight Relationship and Condition Factor of Four Commercial Fish Species of Oyan Lake, Nigeria
}

\author{
Fafioye $\mathbf{O}^{1}$ and Ayodele $\mathbf{O}^{2 *}$ \\ ${ }^{1}$ Department of Zoology and Environmental Biology, Olabisi Onabanjo University, Ago Iwoye, Nigeria \\ ${ }^{2}$ Department of Fisheries Technology, Federal College of Agriculture, Ishiagu, Nigeria \\ *Corresponding author: Ayodele 0, Department of Fisheries Technology, Nigeria
}

Submission: 制 March 03, 2018 ; Published: 眥 December 21, 2018

\begin{abstract}
This study evaluated the Length-Weight Relationship of four commercially available fish species (Coptodon zillii, Oreochromis niloticus, Chrysichthys nigrodigitatus and Brycinus nurse) of Oyan Lake. Eighty adult individuals of each fish species were procured from fishermen in Oyan Lake over a period of 4 months. The fish species were put in sterile polythene bags and taken in icebox to the laboratory. Weight and length of individual fish were measured using Metler balance and a measuring board respectively. Length-weight relationship was analyzed using the equation $\mathrm{W}=\mathrm{a} \mathrm{L}^{\mathrm{b}}$. The condition factor of the fish species was determined using the equation, $\mathrm{K}=100 \mathrm{~W} / \mathrm{L}^{\mathrm{b}}$. The female fish species recorded higher mean Total Length (TL) and mean weight (Wt) in all four fish species examined. However, there was no significant difference $(P>0.05)$ in the mean total body length, mean standard length and mean body weight between the female and the male fish species. The length-weight relationship was observed to be significantly strong ( $\mathrm{P}=0.01)$ in all the four fish species evaluated with Coefficient of determination $\left(\mathrm{R}^{2}\right)$ and the Correlation co-efficient ( $\mathrm{r}$ ) ranging from 0.893 to 0.991 . The condition factor (K) was higher in Coptodon zillii, followed by Oreochromis niloticus, Brycinus nurse and Chrysichthys nigrodigitatus. The growth pattern of Chrysichthys nigrodigitatus was Positive Allometric while the growth pattern of Coptodon zillii, Oreochromis niloticus and Brycinus nurse were Negative Allometric..
\end{abstract}

Keywords: Fish; Length; Growth pattern; Bioaccumulation

\section{Introduction}

The knowledge of quantitative aspects such as length-weight relationship, condition factor, growth and mortality of fishes are important tools for studying fishing biology [1]. Lengthweight relationships can be used to predict weight from length measurements made in the yield assessment [2]. As reported by Nehemia et al. [3] fish can attain either isometric growth, negative allometric growth or positive allometric growth. Isometric growth is associated with no change of body shape as an organism grows. Negative allometric growth implies that the fish becomes slenderer as it increases in weight while positive allometric growth implies the fish becomes relatively stouter or deeper-bodied as it increases in length [4]. In fish, the condition factor has been shown to reflect through its variations, information on the physiological state of the fish in relation to its welfare [5]. It also gives information when comparing two populations living in certain feeding, density, climate, and other conditions; when determining the period of gonadal maturation and when following up the degree of feeding activity of a species to verify whether it is making good use of its feeding source [6,7]. According to Lizama [1], the study of the condition factor is important to understand the life cycle of fish species and contributes to adequate management of the species. Hence, maintaining the equilibrium in the ecosystem [8]. As reported by Fafioye and Oluajo [9], the length-weight relationships data for fresh water and brackish water fish resources of Nigeria are limited. Such water body with limited data on its fish length- weight relationship is the Oyan Lake, Nigeria. The lake is a tributary of the Ogun River used primarily to supply raw water to Lagos and Abeokuta. It is a significant source of fish for the people living in and around Abeokuta. Fish from the lake constitute a great proportion of both fresh and processed fish sold in major fish markets in Abeokuta. To study the condition of the available fish species of Oyan Lake, this study therefore evaluated the lengthweight relationship, condition factor and growth patterns of four commercially available fish species (Coptodon zillii, Oreochromis niloticus, Chrysichthys nigrodigitatus and Brycinus nurse) of the Lake.

\section{Study Area}

This study was carried out at the Oyan River Lake located in Abeokuta North Local Government Area of Ogun State, south-west of Nigeria $\left(7^{\circ} 15^{`} \mathrm{~N} ; 3^{\circ} 16^{`} \mathrm{E}\right)$. The lake is a tributary of the Ogun River used primarily to supply raw water to Lagos and Abeokuta.

\section{Materials and Method}

\section{Sample collection}

Eighty (80) adult fish specimens, twenty each of Coptodon zillii, Oreochromis niloticus, Chrysichthys nigrodigitatus, and Brycinus nurse were procured from fishermen in Oyan Lake over a period of 4 months. The fish species were put in sterile polythene bags and taken in icebox to the laboratory. The total length $(\mathrm{cm})$ and the body 
wet weight (g) of each of the fish samples were measured. Fish were mopped on a pile of filter paper before being weighed to remove excess water from their body in order to ensure accuracy. Weight and length of each individual fish were measured by using a Metler balance and a measuring board respectively. The total lengths $(\mathrm{cm})$ were measured as distance from the snout with mouth closed to the tip of the caudal fin.

\section{Length-weight relationship}

The Length-weight relationship was analyzed by using the equation $W=a L^{b}[2]$. Where $W=$ weight of fish in gram; $L=$ Length of fish in $\mathrm{cm}$; $\mathrm{a}=$ describe the rate of change of weight with length (intercept); and $\mathrm{b}=$ weight at unit length (slope). The equation was log transformed to estimate the parameters ' $a$ ' and ' $b$ '. When $b$ is equal to three (3), isometric pattern of growth occurs but when $b$ is not equal to 3 , allometric pattern of growth occurs, which may be positive if $>3$ or negative if $<3$ [3]. The condition factor which shows the degree of well-being of the fish in their habitat was determined by using the equation, $\mathrm{K}=100 \mathrm{~W} / \mathrm{L}^{\mathrm{b}}[10]$; whereby $\mathrm{K}=$ condition factor; $\mathrm{W}=$ the weight of the fish in gram $(\mathrm{g})$; $\mathrm{L}=$ the total length of the fish in centimeters $(\mathrm{cm})$; and $b=$ the value obtained from the length-weight equation.

\section{Data analysis}

Data were subjected to statistical analyses using the Statistical Package for Social Sciences (SPSS) version 20.0 [11]. Analysis of Variance (ANOVA) and descriptive statistics were used to compare the condition factor $(\mathrm{K})$ between the fish species. Means were presented as Mean \pm Standard error of mean. Means were separated using the Student-Newman-Keuls (SNK). Independent Sample -Test was also used to compare length and weight parameters between the male and the female fish. P-value was set at 0.05 . The regression of weight against length was also computed from the logarithmic formula: $\log a+b \log L$.

\section{Results}

\section{Length weight parameters of the fish species}

Table 1 represents the length weight parameters of both sexes of the fish species of the Oyan Lake. The female fish species recorded higher mean Total Length (TL) and mean weight (Wt) in all the four fish species examined. However, there was no significant difference ( $p>0.05$ ) in the mean total body length, mean standard length and mean body weight between the female and the male fish species.

Table 1: Length weight parameters of both sexes of the fish species

\begin{tabular}{|c|c|c|c|c|c|}
\hline & Sex & TL Range & Mean TL (cm) & Mean SL (cm) & Mean Wt (g) \\
\hline Chrysichthys nigrodigitatus & $\begin{array}{l}\text { Male } \\
\text { Female }\end{array}$ & $\begin{array}{l}21.00-26.00 \\
20.70-26.00\end{array}$ & $\begin{array}{l}23.02 \pm 1.02 \\
23.38 \pm 0.94\end{array}$ & $\begin{array}{l}17.80 \pm 0.97 \\
17.50 \pm 0.69\end{array}$ & $\begin{array}{l}91.20 \pm 14.54 \\
98.60 \pm 12.31\end{array}$ \\
\hline Brycinus nurse & $\begin{array}{l}\text { Male } \\
\text { Female }\end{array}$ & $\begin{array}{l}18.10-26.00 \\
19.50-30.00\end{array}$ & $\begin{array}{l}20.64 \pm 1.39 \\
22.44 \pm 1.93\end{array}$ & $\begin{array}{l}18.52 \pm 1.83 \\
19.00 \pm 1.51\end{array}$ & $\begin{array}{l}104.60 \pm 29.65 \\
138.80 \pm 33.96\end{array}$ \\
\hline Oreochromis niloticus & $\begin{array}{l}\text { Male } \\
\text { Female }\end{array}$ & $\begin{array}{l}19.80-26.50 \\
20.00-26.00\end{array}$ & $\begin{array}{l}22.09 \pm 0.76 \\
23.00 \pm 3.00\end{array}$ & $\begin{array}{l}17.89 \pm 0.51 \\
18.85 \pm 2.35\end{array}$ & $\begin{array}{c}208.38 \pm 21.14 \\
253.00 \pm 103.00\end{array}$ \\
\hline Coptodon zillii & $\begin{array}{l}\text { Male } \\
\text { Female }\end{array}$ & $\begin{array}{l}16.50-25.00 \\
17.50-23.00\end{array}$ & $\begin{array}{l}18.67 \pm 1.09 \\
19.90 \pm 1.63\end{array}$ & $\begin{array}{l}15.21 \pm 0.78 \\
16.00 \pm 1.32\end{array}$ & $\begin{array}{l}141.43 \pm 23.42 \\
166.00 \pm 39.40\end{array}$ \\
\hline
\end{tabular}

Mean significant between the male and the female at $\mathrm{P}<0.05$ (Independent sample T-test); TL=Total length; $\mathrm{SL}=\mathrm{Standard}$ length; Wt=Weight

\section{Length-weight relationship of the fish species}

Table 2: Length-weight relationship of the fish species of Oyan Lake

\begin{tabular}{|c|c|c|c|c|c|c|c|}
\hline Fish spp & $\begin{array}{c}\text { Total length } \\
\mathbf{( c m )}(\mathbf{\pm} \mathbf{S E})\end{array}$ & $\begin{array}{c}\text { Weight } \\
\mathbf{( g )} \mathbf{(} \pm \mathbf{S E})\end{array}$ & $\mathbf{a}$ & $\mathbf{B}$ & $\mathbf{r}$ & $\mathbf{R}^{2}$ & $\mathbf{P}-\mathbf{V a l u e}$ \\
\hline Coptodon zillii & $19.04 \pm 0.87$ & $148.80 \pm 19.33$ & -1.101 & 2.545 & 0.991 & 0.982 & $0.01^{*}$ \\
\hline Oreochromis niloticus & $22.27 \pm 0.76$ & $217.30 \pm 23.44$ & -1.44 & 2.793 & 0.954 & 0.91 & $0.01^{*}$ \\
\hline Chrisichthys nigrodigitatus & $23.20 \pm 0.66$ & $94.90 \pm 9.06$ & -2.694 & 3.411 & 0.975 & 0.951 & $0.01^{*}$ \\
\hline Brycinus nurse & $21.54 \pm 1.16$ & $121.70 \pm 22.00$ & -1.828 & 2.908 & 0.945 & 0.893 & $0.01^{*}$ \\
\hline
\end{tabular}

*Significant relationship exists; $\mathrm{SE}=$ Standard error; $\mathrm{R}^{2}=$ Coefficient of determination; $\mathrm{r}=$ Correlation co-efficient; a=Rate of change of weight with length (intercept); $b=$ weight at unit length (slope)

The Length-Weight relationship of Coptodon zillii, Oreochromis niloticus, Brycinus nurse and Chrysichthys nigrodigitatus from Oyan Lake is presented in Table 2. The length-weight relationship was observed to be significant $(\mathrm{P}=0.01)$ in all the four fish species evaluated. Similarly, the Length-Weight relationship was very strong in the fish species with the Coefficient of determination and the Correlation co-efficient ranging from 0.893to0.991 (Table 2). The graphical representation of the Length-Weight relationship of the fish species is represented in Figure 1. 

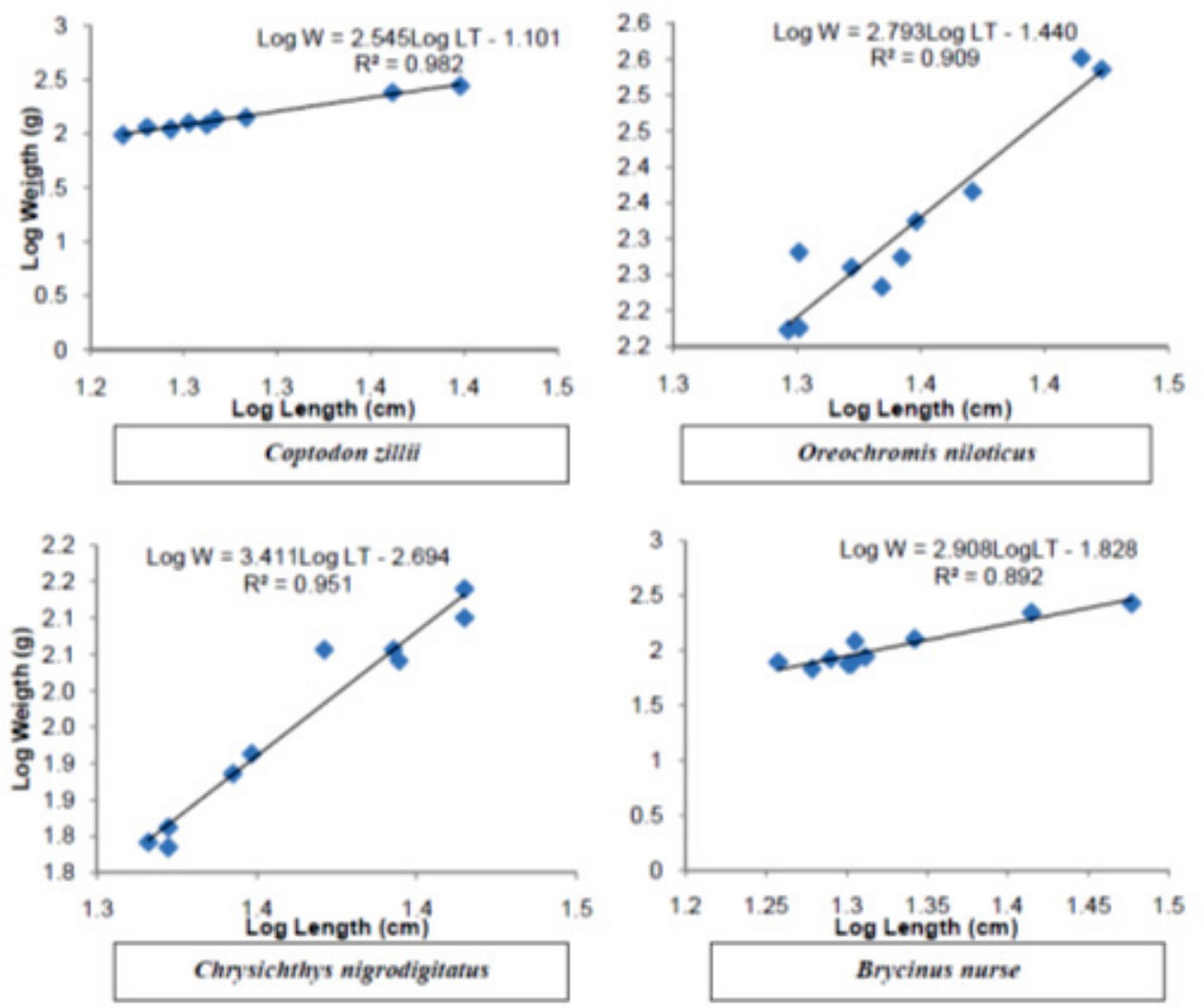

Figure 1: Length-weight relationships of Coptodon zillii, Oreochromis niloticus. Chrysichthys nigrodigitatus and Brycinus nurse.

\section{Condition factor, growth pattern and exponential equa-} tion

The condition factor, growth pattern and exponential equation of the fish species of Oyan Lake are represented in Table 3. The condition factor $(\mathrm{K})$ was significantly $(\mathrm{p}<0.05)$ different between the different fish species. This was higher in the Coptodon zillii and followed by Oreochromis niloticus, Brycinus nurse and Chrysichthys nigrodigitatus respectively. The growth pattern of Chrysichthys nigrodigitatus was identified as Positive Allometric (b value greater than 3.0) while the growth pattern of Coptodon zillii, Oreochromis niloticus and Brycinus nurse were identified as Negative Allometric (b value less than 3.0). The length-weight equation obtained for each of the fish species is also presented in Table 3.

Table 3: Condition factor, growth pattern and exponential equation of the fish species of Oyan Lake.

\begin{tabular}{|c|c|c|c|c|}
\hline & Condition Factor $(\mathbf{K})$ & B & Growth Type & Exponential Equation \\
\hline Coptodon zillii & $2.09 \pm 0.05^{\mathrm{a}}$ & 2.793 & Negative Allometric & $\mathrm{Wt}=1.101(\mathrm{TL})^{2.55}$ \\
\hline Oreochromis niloticus & $1.92 \pm 0.06^{\mathrm{b}}$ & 2.545 & Negative Allometric & $\mathrm{Wt}=1.440(\mathrm{TL})^{2.79}$ \\
\hline Chrysichthys nigrodigitatus & $0.74 \pm 0.02^{\mathrm{d}}$ & 3.411 & Positive Allometric & $\mathrm{Wt}=2.694(\mathrm{TL})^{3.41}$ \\
\hline Brycinus nurse & $1.14 \pm 0.06^{\mathrm{c}}$ & 2.908 & Negative Allometric & $\mathrm{Wt}=1.828(\mathrm{TL})^{2.91}$ \\
\hline
\end{tabular}

${ }^{a b c}$ Mean ( \pm Standard error) having similar superscript is significantly different at $\mathrm{P}<0.05$. Wt=Weight; TL=Total Length

\section{Discussion}

This present study has demonstrated the variations in the condition factor, growth pattern and the length-weight relationship of the commercially available fish species of Oyan Lake, Nigeria (Coptodon zillii, Oreochromis niloticus, Chrysichthys nigrodigitatus, and Brycinus nurse). C. zillii was highest in condition factor (K) than the other fish species of Oyan Lake evaluated. In fisheries science, the condition factor is used in order to compare the condition, fatness or wellbeing of fish [5]. Condition factor is also a useful index for monitoring of feeding intensity, age and growth rates in fish [12]. As reported by Abobi and Ekau [13], condition factor defines the state of wellbeing of the fish and reflects through variations, some information on the physiology of the fish, and it is assumed that the higher the value of condition factor, the better the state of wellbeing. Hence, it could be suggested that the condition of Oyan Lake is more favourable to $C$. zillii than the other fish species evaluated. Condition factor $(\mathrm{K})$ recorded in C. zillii, B. nurse and 0 . niloticus were greater than one $(>1)$. Nehemia et al. [3] earlier reported that K-value which is greater than one signifies that a fish is in good condition. $\mathrm{K}$-values greater than one as recorded for $C$. 
zillii, $B$. nurse and $O$. niloticus in this study could therefore be an indication that Oyan Lake provide a good habitat for these fishes to thrive. On the other hand, K-value less than one as recorded for C. nigrodigitatus suggested that the conditions of Oyan Lake might not be completely favourable for the well-being of the fish. Fafioye and Oluajo [9] also reported a K-value less than one for Chrysichthys nigrodigitatus in Epe Lagoon, Nigeria.

The length-weight relationship (LWR) is an important tool that provides information on growth patterns and growth of animals [5]. The $b$ values in length-weight relationships have been used to determine the growth pattern of fish species. According to Alam et al. [14], the value of $b$ is an exponent indicating an isometric growth when equal to 3 and indicating an allometric growth when significantly different from 3. From this study, C. zillii, B. nurse and $O$. niloticus were observed to have a negative allometric growth pattern with $b$ value less than 3.0. Earlier researches reported that negative allometric growth pattern with $b$ value less than 3.0 exist in C. zillii $[8,3,15,16]$, in B. nurse [17] and in 0 . niloticus $[8,16]$. However, $C$. nigrodigitatus had a positive allometric growth pattern with b value greater than 3.0. A similar result was reported for $C$. nigrodigitatus of Epe Lagoon, Nigeria [9]. The values of $\mathrm{R}^{2}$ ranged from 0.893 to0.982 in B. nurse, O. niloticus, $C$. zillii and $C$. nigrodigitatus and all regressions were highly significant $(\mathrm{P}=0.01)$. This was an indication that the body weight of the fish species could be estimated with a high degree of accuracy from known standard lengths $[17,18]$.

\section{References}

1. Lizama M, los AP, Ambrósio AM (2002) Condition factor in nine species of fish of the characidae family in the upper paraná river floodplain, brazil. Braz J Biol 62(1): 113-124.

2. Pauly D (1993) Linear regressions in fisheries research. Journal of the Fisheries Research Board of Canada 30: 409-434.

3. Nehemia A, Justin D, Maganira, Cyrus, Rumisha (2012) Length-weight relationship and condition factor of coptodon species grown in marine and fresh water ponds. Agriculture and Biology Journal of North America 3(3): 117-124.

4. Riedel R, Caskey LM, Hurlbert SH (2007) Length-weight relations and growth rates of dominant fishes of the Salton Sea: implications for predation by fish-eating birds. Lake and Reservoir Management 23(5): 528-535.

5. Ighwela KA, Ahmed AB, Abol Munafi AB (2011) Condition factor as an indicator of growth and feeding intensity of nile tilapia fingerlings
(Oreochromis niloticus) feed on different levels of maltose. AmericanEurasian J Agric \& Environ Sci 11(4): 559-563.

6. Anyanwu AO, Okoro BC, Ebonwu BI, Ihimekpen F, Ayaobu IKC, et al. (2007) Length-weight relationship, condition factor and sex ratio of african mudcatfish (Clarias gariepinus) reared in indoor water recirculation system tanks. Res Biol Sci 2(1): 780-783.

7. Wootton RJ (1990) Fish \& Fisheries Series. In: Chapman and Hall (Eds.), Ecology of Teleost Fishes (ebn), UK, ISBN-13: 9780412317200, P 404.

8. Imam TS, Bala U, Balarabe ML, Oyeyi TI (2010) Length-weight relationship and condition factor of four fish species from wasai reservoir in kano, Nigeria. African Studies 6(3): 125-130.

9. Fafioye 00, Oluajo OA (2005) Length-Weight Relationships of five fish species in Epe Lagoon, Nigeria. African Journal of Biotechnology, 4(7): 749-751.

10. Gomiero LM, Braga FMS (2005) The condition factor of fishes from two river basins in Sao Paulo state, Southeast of Brazil. Acta Scientiarum 27(1): 73-78.

11. IBM Corporation (2011) IBM SPSS statistics for Windows, version 20.0. Armonk, NY: IBM Corp

12. Ndimele PE, Johnson KCA, Aladetohun NF, Ayorinde OA (2010) Lengthweight relationship, condition factor and dietary composition of Sarotherodon melanotheron, Ruppell, 1852 (Pisces: Cichlidae) in ologe lagoon, lagos, Nigeria. Agric Biol J North Am 1(4): 584-590.

13. Abobi SM, Ekau W (2013) Length-weight relationships and condition factors of Alestes baremoze, Brycinus nurse and Schilbe intermedius from the lower reaches of white volta river (Yapei), Ghana. Int J Fish Aquaculture 5(6): 152-165.

14. Alam MM, Rahman MT, Parween S (2014) Morphometric characters and condition factors of five freshwater fishes from Pagla river of Bangladesh. International Journal of Aquatic Biology 2(1): 14-19.

15. Bala U, Lawal I, Bolorunduro PI, Oniye SJ, Abdullahi SA, et al. (2009) Study of ichthyofauna of Daberam reservoir in Katsina State. Bayero Journal of Pure and Applied Sciences 2: 172-174.

16. Kishiya DAS (2013) Length-weight relationship and condition factor of five fish species from a tropical water supply reservoir in Abuja, Nigeria. American Journal of Research Communication 1(9): 175-187.

17.Ezenwaji, Ngozi E, Ezenwaji, Henry MG (2009) Length-weight relationships and condition factor of Citharinus citharus and Alestes baremose from Anambra river basin, Nigeria. Animal Research International 6(3): 1107-1109.

18. Ahmed EO, Ali ME, Aziz AA (2011) Length-weight relationships and condition factors of six fish species in Atbara river and khashm el-girba reservoir, Sudan. International Journal of Agriculture Sciences 3(1): 6570.
Creative Commons Attribution 4.0 International License

For possible submissions Click Here

\section{Submit Article}

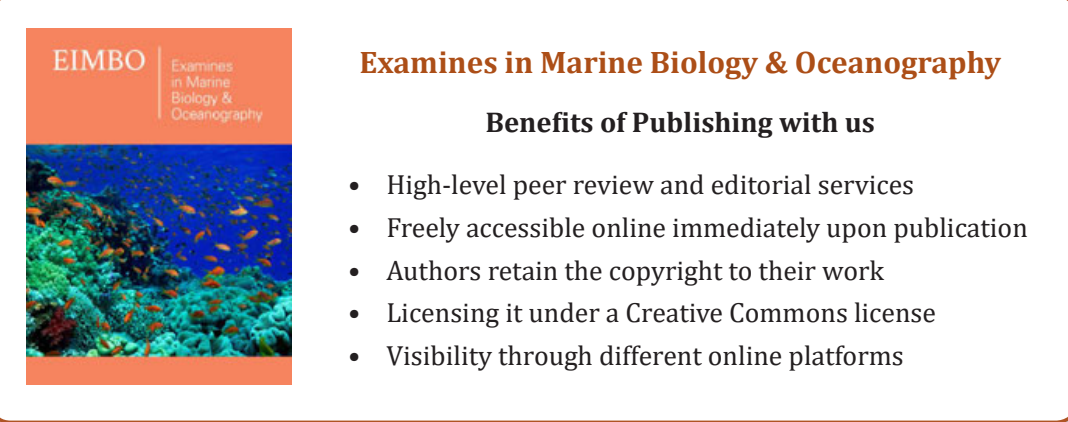

